\title{
Sustainable development and international cooperation in the Eastern Nile Basin
}

\section{Journal Article}

\section{Author(s):}

Amer, Salah El-Din; Arsano, Yacob; El-Battahani, Atta; Hamad, Osman El-Tom; Hefny, Magdy A.E.; Tamrat, Imeru; Mason, Simon Jonas Augusto (D)

Publication date:

2005-03

Permanent link:

https://doi.org/10.3929/ethz-b-000046608

Rights / license:

In Copyright - Non-Commercial Use Permitted

Originally published in:

Aquatic Sciences 67(1), https://doi.org/10.1007/s00027-004-0764-z 


\title{
Special Feature Article
}

\section{Sustainable development and international cooperation in the Eastern Nile Basin}

\author{
Salah El-Din Amer ${ }^{1}$, Yacob Arsano ${ }^{2}$, Atta El-Battahani ${ }^{3}$, Osman El-Tom Hamad ${ }^{4}$, \\ Magdy Abd El-Moenim Hefny ${ }^{5}$ and Imeru Tamrat ${ }^{6}$, authors in alphabetical order* \\ ${ }^{1}$ University of Cairo, Faculty of Law, 6 Tahrir Street, Dokki, Giza, Cairo, Egypt \\ 2 Addis Ababa University, Department of Political Sciences and International Relations, P.O. Box 1176, \\ Addis Ababa, Ethiopia \\ ${ }^{3}$ University of Khartoum, Department of Political Science, P.O. Box 321, Code 11115, Khartoum, Sudan \\ ${ }^{4}$ Water Resources Project, Nile Basin Initiative, GTZ office, P.O. Box 12631, Addis Ababa, Ethiopia \\ (prior address: Ministry of Irrigation and Water Resource, Khartoum, Sudan) \\ ${ }^{5}$ Regional Center for Studies and Research of Water Ethics. Ministry of Water Resources and Irrigation, \\ Fum Ismaillia Canal P.O. Box 74, Shubra El Kheima, 13411 Egypt \\ ${ }^{6}$ Policy, Law, Water Resources and Environmental Management Consultancy, P.O. Box 864, Code No. 1110, \\ Addis Ababa, Ethiopia
}

Received: 11 June 2004; revised manuscript accepted: 11 November 2004

\begin{abstract}
The following article provides an overview of issues related to international cooperation and water use in the Eastern Nile Basin, thereby introducing the following three papers written from an Ethiopian, Sudanese and Egyptian perspective respectively. Basic environmental and socio-economic data is given. The various national interests and international initiatives in the Nile Basin are introduced. Key areas of consensus between the authors,
\end{abstract}

as well as open questions that still need to be worked on, are elaborated. The article also describes the unique process of how the six authors from three countries worked on this joint publication in the Nile Dialogue Workshop of 2002. Key conclusions are that sustained, non-polemical communication can lead to cooperation, and that cooperation is the cornerstone to sustainable water development.

Key words. Nile Basin Initiative; international river management; cooperation through communication; transboundary water resources; Egypt; Sudan; Ethiopia.

\section{Introduction}

How can large groups of people use limited natural resources in a sustainable and cooperative way? The Nile Basin, with more than 160 million people living in ten different countries (Fig. 1) and sharing a common fresh-

\footnotetext{
* Correspondence regarding this article should be sent to the coordinator of this special feature: Simon A. Mason, Center for Security Studies, Center for Comparative and International Studies, ETH Zurich, 8092 Zurich, Switzerland. Phone: +41 163267 67; fax: +41 163219 41; e-mail: mason@sipo.gess.ethz.ch Published on Web: March 2, 2005
}

water resource, is a superlative paradigm that can shed light on these questions. Egypt is the most downstream country in the Nile Basin with more than $96 \%$ of its freshwater inflow originating from outside its national boundaries. Irrigated agriculture is, and has been for thousands of years, an integral part of Egypt's economy and culture (Hefny and Amer, 2005). Ethiopia, the most upstream country in the Eastern Nile Basin ${ }^{1}$, is the source of $86 \%$ of the Nile flow, as measured at Aswan. Ethiopia is cur-

\footnotetext{
1 Since Eritrea is not a main contributor to the Nile flow, or a main dependent on the Nile, we do not describe it here in detail.
} 
rently developing its water resources for much needed economic development, both for hydro-electric power and irrigation (Arsano and Tamrat, 2005). Sudan is upstream of Egypt and downstream of Ethiopia and acts as a source, path and drainage basin for the Nile (Hamad and El-Battahani, 2005).

When multiple users share a limited resource, this does not necessarily have to result in conflict. In fact, under some circumstances, it may necessarily lead to cooperation. Although there is a plethora of literature about internationally shared water resources, very little has been written jointly by academics from the various countries that are involved ${ }^{2}$. The integrated and participatory ${ }^{3}$ management of international rivers is, therefore, not just the focus of this paper, but also the criterion by which it was developed. This paper was written during a period that may prove to be historic for the people of the Nile Basin. In 1997 a Panel of Experts, three from each country, were instructed by their ministers for water affairs to come up with a cooperative legal and institutional framework for all the Nile Basin countries. Three years later, the panel presented a text in which they agreed on some of the issues and differed on others, as expected. A Negotiating Committee was delegated by the nine Nile Basin countries to deliberate on the text. While waiting for the legal and institutional framework to materialize, the governments of the Nile Basin countries launched the Nile Basin Initiative in 1999; this is a transitional framework, which aims to achieve "sustainable socio-economic development through the equitable utilization of, and benefit from, the common Nile Basin water resources." (NBI, 2000).

Consistent with these indicators of cooperation, the Swiss Federal Institute for Environmental Science and Technology (EAWAG) and the Center for Comparative and International Studies of the Swiss Federal Institute of Technology (ETH Zurich) organized a workshop on "Sustainable Development ${ }^{4}$ and International Cooperation in the Eastern Nile Basin" in August of 2002 in Kastanienbaum, Switzerland ${ }^{5}$. Academics from Egypt, Ethiopia and Sudan were invited to the workshop with the aim of clarifying the issues at stake and contributing to the ongoing cooperative efforts. Their personal contributions and participation in the workshop do not, however, necessarily represent the views of any government or in-

\footnotetext{
2 An example of literature on water resources in the Nile Basin that was developed by government consultants of the respective countries are the publications of the Nile Basin Initiative in preparation of the ICCON, see NBI (2001).

3 The participatory approach is understood here to mean specifically the involvement of all riparian countries in any decision-making, as they are directly affected by any water development projects in the Nile Basin. Outsiders play a facilitating and supporting role. ${ }^{4}$ Sustainable development is understood here as socio-economic development that safeguards the resource base for future generations, taking possible long-term and off-site resource use implications into consideration.
}

stitution. The workshop methodology is described in Mason (2004).

The following three articles in this special feature describe the availability of water resources and their use and management on the national level in Egypt, Ethiopia and Sudan, respectively. The authors focus on international relations, open questions and lessons learned about international cooperation in the Eastern Nile Basin. While national backgrounds have an influence on their perspectives, the authors write in their individual capacities as academics and water experts from different disciplines (law, hydrology, economics and political science). This introduction to the three articles highlights some of the common issues and concerns and allows for a cursory comparison between the countries of the Eastern Nile Basin. It ends with 'lessons learned' - the content of which was developed jointly by the authors during the EAWAG-CIS workshop. The major questions explored and answered by the authors include:

1) What are the interests and needs of Egypt, Ethiopia and Sudan with regard to the use and management of water resources in the Nile Basin?

2) What do Egypt, Ethiopia and Sudan expect from international cooperation, and what are they prepared to do to enhance it?

3) On what issues is there consensus?

4) In what areas are there still open questions?

5) What are the options for dealing with these open questions?

\section{Availability and use of environmental resources in the Nile Basin}

The main environmental issues in the Nile Basin include water for irrigation and hydro-electric power production (HEP), flood prevention, erosion and siltation of reservoirs, and water pollution prevention. The Nile Basin covers an area of 3.1 million $\mathrm{km}^{2}$ of which $3 \%$ is covered by wetlands, $3 \%$ by open water, $2 \%$ by forests and $1.4 \%$ by irrigated land (NBI, 2001). Measured at Aswan, the

\footnotetext{
${ }^{5}$ Participants in the workshop were the six authors of this paper. The workshop was organized by Prof. Dr. Alexander J.B. Zehnder, EAWAG (Swiss Federal Institute for Environmental Science and Technology), and Prof. Dr. Kurt R. Spillmann, Center for Security Studies (CSS), member of the Center for Comparative and International Studies (CIS), Swiss Federal Institute of Technology, moderated by Dr. Günther Baechler, SDC (Swiss Agency for Development and Cooperation), and Dr. Hansueli Müller-Yersin, OECONSULT, coordination by Simon A. Mason, EAWAG/CSS/CIS, and organizational assistance from Marwa Gouda, CSS/CIS. Financial support provided by the Individual Project IP7 "Environmental Change and Conflict Transformation" of the NCCR North-South "Research Partnerships for Mitigating Syndromes of Global Change", funded by the Swiss National Science Foundation (SNSF) and the Swiss Agency for Development and Cooperation (SDC) (see http://www.nccr-north-south-unibe.ch) is acknowledged.
} 


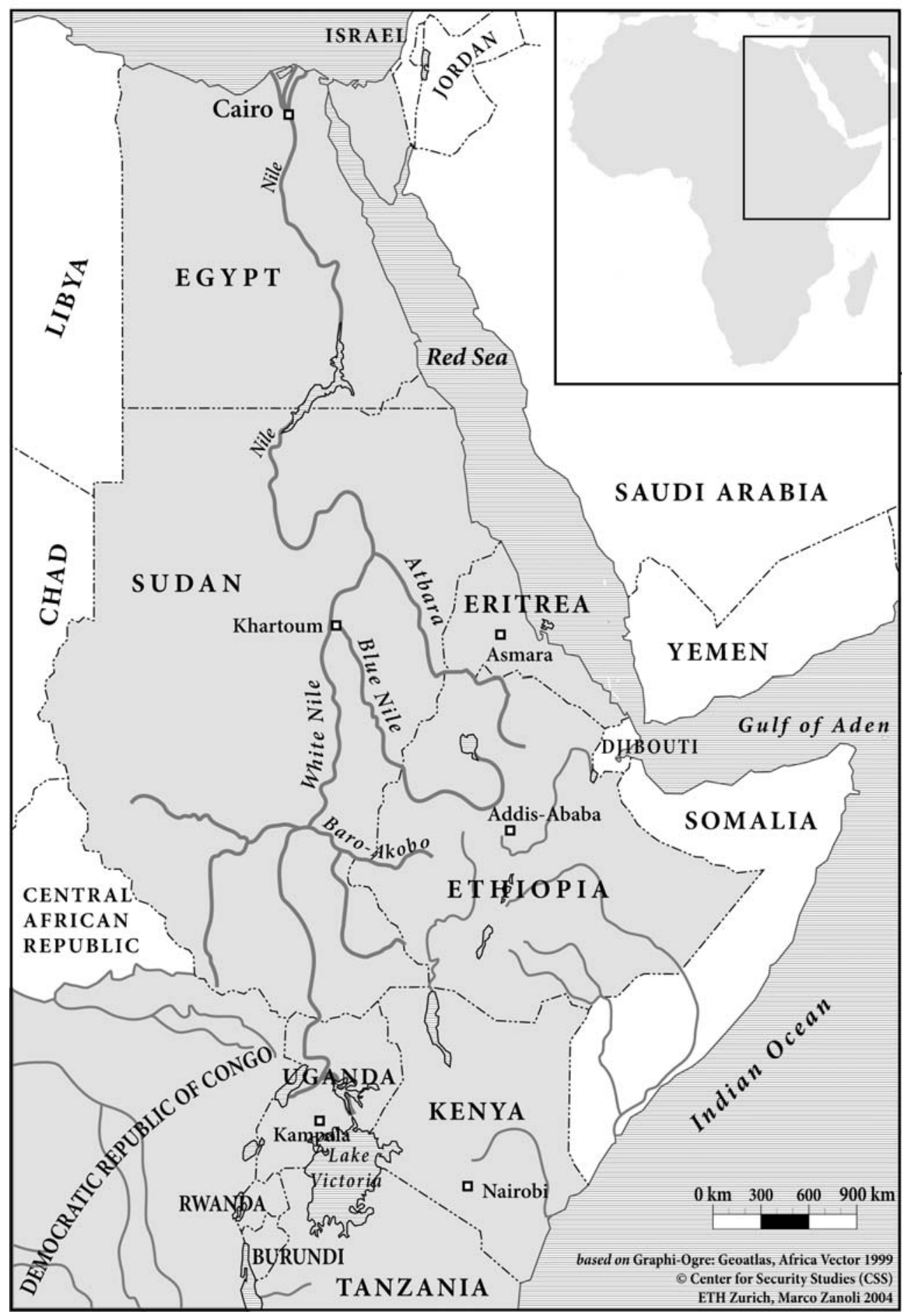

Figure 1. Countries of the Nile Basin. The Nile Basin includes two main sub-basins: the Eastern Nile Sub-basin (Egypt, Ethiopia, Eritrea and Sudan) and the Equatorial Lakes Sub-basin (Burundi, Dem. Rep. of Congo, Egypt, Kenya, Rwanda, Sudan, Tanzania and Uganda). The White and Blue Nile join in Sudan and then flow on to Egypt. The country borders do not represent officially recognized country borders. Approximate and schematic lines have been included only to clarify the geographical position of the countries in relation to the main Nile tributaries. 


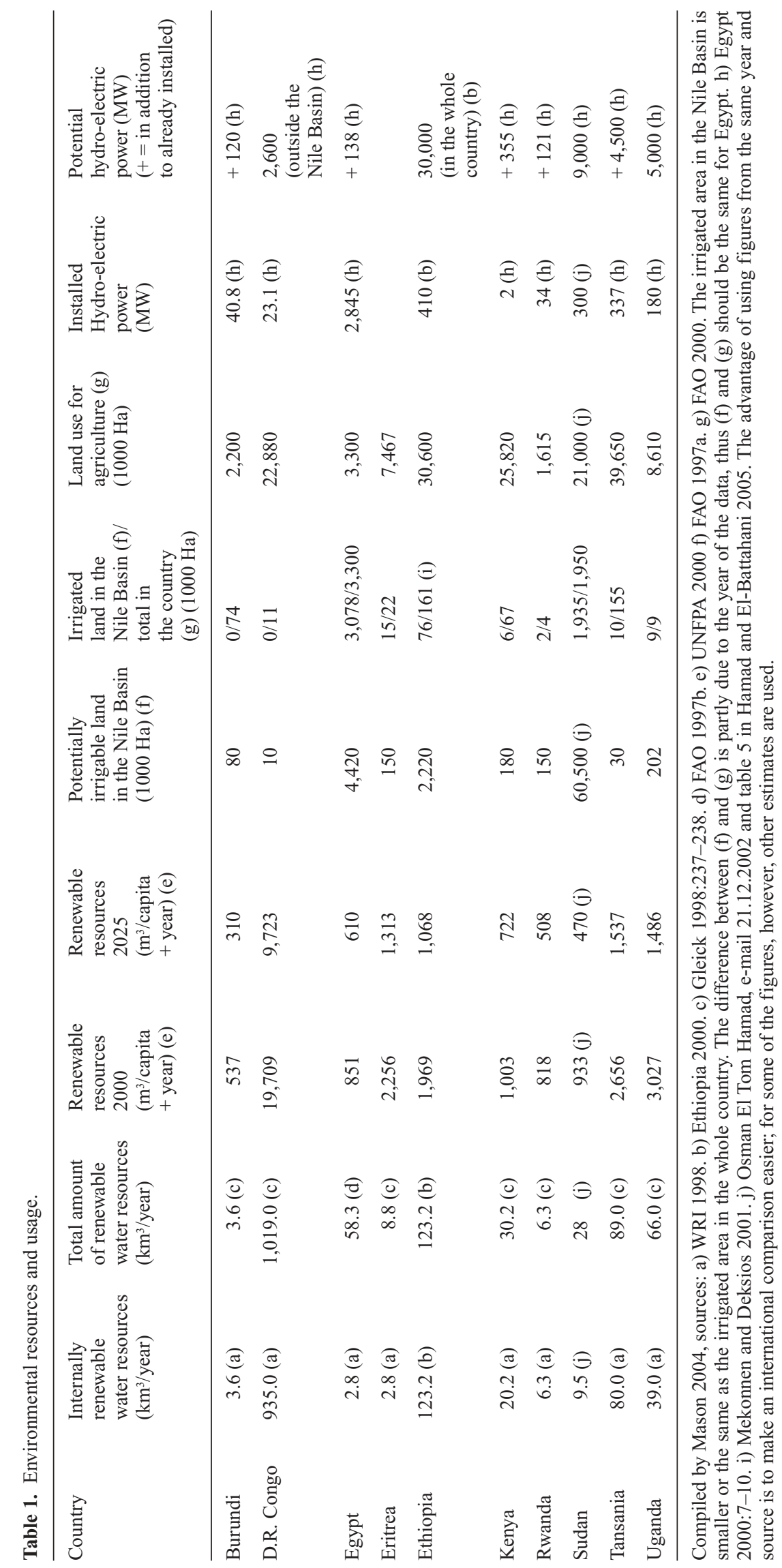


Nile River had an average annual flow of $84 \mathrm{~km}^{3}$ between the years 1900 and 1959 (Agreement, 1959). However, much of the water is lost by evaporation. The extreme range of flow values for the years $1916\left(120 \mathrm{~km}^{3} /\right.$ year $)$ and $1984\left(42 \mathrm{~km}^{3} /\right.$ year $)$ demonstrate the enormous fluctuations in the natural Nile flow (Collins, 1990). The distribution of water is also disproportionate on a temporal scale, with some $70 \%$ of the annual precipitation in the Ethiopian highlands occurring between June and September (Conway, 2000). Water is also distributed unevenly within the Basin, resulting in climates ranging anywhere from rainforest to desert.

Generally, a country is considered to be 'absolutely water scarce' if it has less than 500 cubic meters per capita per annum, as 'chronically water scarce' with $500-1000 \mathrm{~m}^{3} / \mathrm{capita}$ per year, and as 'water stressed' with $1000-1700 \mathrm{~m}^{3} /$ person per year. With greater than $1700 \mathrm{~m}^{3} /$ person per year available, countries tend to only experience occasional or local water problems (Falkenmark and Widstrand, 1992). In Table 1 one can see that Egypt, Sudan, Rwanda and Burundi fall in the category of 'chronically water scarce' countries, while Kenya is classified as 'water stressed'. The uneven distribution of rain in Ethiopia demonstrates, however, that care is needed when using these classifications, as they do not take into account seasonal and/or geographic differences in the distribution of water resources within a given country.

More than $86 \%$ of water in the Eastern Nile Basin is used for agriculture (WRI, 1998). Since irrigation is the main consumptive water use, it is more contentious on the international stage than water used for hydro-electric power production. The FAO estimates that the amount of irrigable land in the Nile Basin is greater than the amount of water available in the Basin (FAO, 1997a). The enormous savings potential that could be realized with increased efficiency in irrigated agriculture should be mentioned here: FAO estimates are based on an average water use requirement within the region of $12,000 \mathrm{~m}^{3} / \mathrm{ha}$ per year. The International Water Management Institute estimates that $50 \%$ of the total increase in world water demand could be satisfied by the year 2025 through increased efficiency in irrigated agriculture (Seckler et al., 1998). Nevertheless, water is a limiting factor to irrigated agriculture and food production in the Nile region and worldwide. According to the FAO (1997a), about $50 \%$ of irrigable land is already under irrigation in the Nile Basin. See Table 1 for figures of potentially irrigable land in the Nile Basin.

The potential to develop hydro-electric power in the Nile Basin is enormous; only $1 \%$ of the estimated potential has so far been realized. The greatest development potential, about $58 \%$ of the total in the Nile Basin, is located in Ethiopia; this is because of the great differences in altitude (Table 1). Hydro-electric power is needed to support economic alternatives to agriculture. HEP is not, however, limited by water availability, but by socio-economic, political and physical difficulties that need to be addressed in order to build the necessary storage capacity.

The Nile countries are not only linked by common water resources; problems of erosion upstream and sedimentation downstream are likewise closely associated and of mutual concern (Fig. 1). Ethiopia's annual loss of topsoil in the Nile Basin is estimated at more than 520 million cubic meters (EVDSA, 1991; Arsano, forthcoming). Silt accumulation in the reservoirs in downstream Sudan and Egypt and mitigation of future pollution hazards must be managed as common problems requiring cooperation among all affected countries.

\section{National interests in international cooperation}

The following section outlines the national interests of Ethiopia, Sudan and Egypt in international cooperation, based on the three papers that follow in this feature.

Table 2. Demographic and economic indicators.

\begin{tabular}{|c|c|c|c|c|c|c|}
\hline Country & $\begin{array}{l}\text { Total } \\
\text { population } \\
2001 \\
\text { (millions) }\end{array}$ & $\begin{array}{l}\text { Projected } \\
\text { population } \\
2050 \\
\text { (millions) }\end{array}$ & $\begin{array}{l}\text { Average } \\
\text { population } \\
\text { growth rate } \\
2000-2005(\%)\end{array}$ & $\begin{array}{l}\text { Population/ha } \\
\text { arable and } \\
\text { perm. crop } \\
\text { land }\end{array}$ & $\begin{array}{l}\text { GDP per } \\
\text { capita ppp \$ } \\
1999\end{array}$ & $\begin{array}{l}\text { Access to } \\
\text { safe water } \\
(\%)\end{array}$ \\
\hline Burundi & 6.5 & 20.2 & 3.0 & 5.3 & 570 & \\
\hline D.R. Congo & 52.5 & 203.5 & 3.3 & 4 & & 45 \\
\hline Egypt & 69.1 & 113.8 & 1.7 & 7.6 & 3460 & 95 \\
\hline Eritrea & 3.8 & 10.0 & 4.2 & 5.6 & 1040 & 46 \\
\hline Ethiopia & 64.5 & 186.5 & 2.4 & 4.7 & 620 & 24 \\
\hline Kenya & 31.3 & 55.4 & 1.9 & 4.9 & 1010 & 49 \\
\hline Rwanda & 7.9 & 18.5 & 2.1 & 5.6 & 880 & 41 \\
\hline Sudan & 31.8 & 63.5 & 2.3 & 1.1 & & 75 \\
\hline Tansania & 36 & 85.7 & 2.3 & 5.5 & 500 & 54 \\
\hline Uganda & 24.0 & 101.5 & 3.2 & 2.4 & 1160 & 50 \\
\hline
\end{tabular}

Source: UNFPA 2001. 


\section{Ethiopia}

Ethiopia is interested in using the waters of the Nile to alleviate poverty and enhance long-term economic development. Water development is planned for both smalland large-scale irrigation projects as well as for hydroelectric power generation to support electrification. Due to the high variability in annual rainfall, conservation of water and irrigated agriculture are seen as a way to mitigate the effects of drought. Soil conservation and watershed management are viewed as important aspects of water resource development, with the potential positive effects of reduced siltation downstream and a more regulated flow that would ease the danger of floods in Sudan. But Ethiopia is concerned that downstream countries will attempt to prevent implementation of such water development projects by blocking investments of international institutions and funding agencies. This is why Ethiopia is interested in establishing an institutional and legal framework for the joint utilization of transboundary water that would establish equitable water shares and water utilization for all riparian countries (Arsano and Tamrat, 2005).

\section{Sudan}

Sudan is threatened by recurrent flooding and droughts and is therefore interested in international cooperation to both forecast and mitigate floods and droughts. Sudan is also supportive of regulated water flow and watershed management. At present, siltation of its reservoirs and irrigation channels is negatively affecting both agricultural production and Sudan's capacity to produce hydro-electric power. Sudan is interested in an open information policy because it is dependent on water coming from Ethiopia and the Equatorial Lakes and projects upstream may affect the flow of water to Sudan. The benefits of dams in Ethiopia, leading to a more regulated flow and reduced sedimentation, and the possibility of joint multicountry projects to use water optimally may outweigh any negative aspects (Hamad and El-Battahani, 2005).

\section{Egypt}

Egypt is committed to safeguarding the water resources it is so dependent upon. It would like its upstream neighbors to accept its historic rights to the amount of water it has been using since the Aswan High Dam was built. The Aswan Dam reduced the amount of water that was lost to the sea by $32 \mathrm{~km}^{3} /$ year. In order to better understand the impact of water projects upstream, Egypt would like to exchange data and information as well as modeling and pilot projects that could help assess the impact of such projects. An international extension of the electricity network and prevention and monitoring of water pollution are additional priorities that Egypt believes should be handled through cooperation with upstream countries.
These positions are consistent with Egypt's long-term aim of increasing economic ties among the Nile Basin nations (Hefny and Amer, 2005).

\section{International initiatives}

The following international initiatives in the Nile Basin are discussed and analyzed in the following papers from each of the three country's perspective: the Hydromet project (1967-1992), Undugu (1983-1989), and TECCONILE (1992-1999). Overall, it has been acknowledged that, in spite of their merits, these initiatives were incomplete because they did not include all the Nile Basin countries.

It has already been noted that the Nile Basin Initiative is different from previous efforts. The NBI is guided by a shared vision: " $\ldots$ to achieve sustainable socio-economic development through the equitable utilization of, and benefit from, the common Nile Basin Water resources." Unlike previous initiatives, all Nile Basin countries (with the exception of Eritrea which is now thinking of membership) joined the NBI. The NBI is a transitional mechanism for working together until the permanent Cooperative Framework is agreed upon. The "D3" project, and more recently a Negotiating Committee, are the forums within the NBI where this future permanent Cooperative Framework is being discussed and developed. At the top level, the NBI is comprised of the Council of Ministers of Water Affairs of the Nile Basin States (Nile-COM) and will provide policy guidance. A Nile Technical Advisory Committee (Nile-TAC) is composed of two technical experts from each member country and oversees the joint programs and projects incorporated in the NBI. It also serves as an advisory body to the Nile-COM.

The NBI has two complementary tracks: a basin-wide Shared Vision Program (SVP) and a sub-basin Subsidiary Action Program (SAP). The SVP aims to pave the way for the SAP and to strengthen cooperation in the Nile Basin by building human and institutional capacity, and by creating the opportunity for basin-wide dialogue. Eight projects have been agreed upon under the SVP: these include the areas of transboundary environment, regional power trade, efficient use of water for agriculture, integrated water resource planning and management ${ }^{6}$, confidencebuilding, and applied training and benefit-sharing opportunities as well as a project to oversee the coordination of the SVP projects. The SAP intends to identify and implement water resource development projects that confer mutual benefits to the Nile Basin nations. It is subdivided into the Eastern Nile region (EN) and the Nile Equatorial

\footnotetext{
${ }^{6}$ Integrated water resource management is understood here as an intersecting approach that considers physical aspects of water resources, environmental sustainability, and all relevant stakeholders.
} 
Lakes region (NEL). The ENSAP has agreed to include activities for watershed protection and management, water conservation, hydro-electric power development and trade, and the development of agriculture and irrigation. These projects were presented to the international community during the first meeting of the International Consortium for Cooperation on the Nile (ICCON) in Geneva in June 2001. Over the three years since ICCON, both the SVP and SAP have gained momentum and show promising steps for joint work and investment (Hamad and ElBattahani, 2005).

\section{Consensus}

The authors have reached consensus on a number of issues:

- All three countries are willing and committed to cooperate over shared water resources through the Nile Basin Initiative process.

- All three countries agree to develop joint and mutually beneficial projects, including those involving watershed management, HEP and joint irrigation projects (with initial projects between Ethiopia and Sudan on the Tekezi/Atbara River and the Baro-Akobo/ Sobat River to test the impact).

- As a concrete sign of working together for the benefit of their shared resources the three countries of the Eastern Nile Basin have already established the ENSAP secretariat (the Eastern Nile Technical Regional Office, ENTRO) to oversee implementation.

- The Nile Basin countries are in the process of discussing legal and institutional questions. This first occurred in the D3 project; more recently, it is a part of the NBI Negotiating Committee.

- The Nile Basin Countries have agreed on a Shared Vision and on other "soft" projects under the SVP, such as capacity-building endeavors.

\section{Open questions}

The authors also reflected on the following open questions:

- How will data and information exchange occur when a riparian state announces plans for water use?

- What legal and institutional issues remain to be discussed?

- How can equitable use be insured without causing significant harm?

- What is the potential for obtaining investment funding for development projects?

- How can the participatory process best be strengthened?

\section{EAWAG-CIS workshop}

During the EAWAG-CIS workshop on "Sustainable Development and International Cooperation in the Eastern Nile Basin", different challenges and opportunities for international cooperation and sustainable development were brainstormed. The various items were grouped and rated according to their perceived importance as regards the further work of the group; they are summarized in Table 3.

The three challenges to which the greatest importance was assigned were: (1) uneven development and regional differences; (2) the importance of looking for long-term gains and shared interests; and (3) the challenge of poverty. With regard to perceived opportunities, the following three issues were given the greatest weight: (1) the development of joint projects for the benefit of all; (2) the need for external third-party support (such as partners in the Nile Basin Initiative); and (3) the maintenance of the momentum of progress made by the Nile Basin Initiative.

Table 3. Priority ranking of the challenges and opportunities in the Nile Basin to be discussed in the workshop.

\begin{tabular}{ll}
\hline & $\begin{array}{l}\mathrm{X}=\text { Priority/ } \\
\text { importance }\end{array}$ \\
\hline $\begin{array}{l}\text { Challenges: } \\
\text { uneven development (regional differences) } \\
\text { need for institutional and legal framework }\end{array}$ & $\mathrm{X}$ X X \\
$\begin{array}{l}\text { national emphasis on long-term gains } \\
\text { and shared interests }\end{array}$ & $\mathrm{X}$ X X \\
$\begin{array}{l}\text { water scarcity, efficient water use, } \\
\text { increase supply }\end{array}$ & $\mathrm{X}$ \\
$\begin{array}{l}\text { diversity } \\
\text { stakeholder involvement } \\
\text { poverty } \\
\text { confidence, trust } \\
\text { environmental degradation } \\
\text { population growth } \\
\text { globalization } \\
\text { instability (regional) }\end{array}$ & $\mathrm{X}$ \\
$\begin{array}{l}\text { Opportunities: } \\
\text { joint projects for the benefit of all } \\
\text { awareness of the issues } \\
\text { win-win solutions (applied/operationally) } \\
\text { step by step approach } \\
\text { external support, third-party assistance }\end{array}$ & $\mathrm{X}$ X X \\
$\begin{array}{l}\text { (systems approach } \\
\text { unity in diversity } \\
\text { shifting paradigms, cooperation } \\
\text { existing linkages, (physical/cultural), } \\
\text { common ground } \\
\text { empathy (mutually) } \\
\text { progress made under NBI (momentum) }\end{array}$ & $\mathrm{X}$ X \\
\hline
\end{tabular}

a Systems view means here a holistic approach that is based on a comprehensiveness and interconnectedness of hydrological, economic, political, social and environmental concerns, with humans at the center of the complex management problem. Problems are tackled simultaneously because they are linked. 


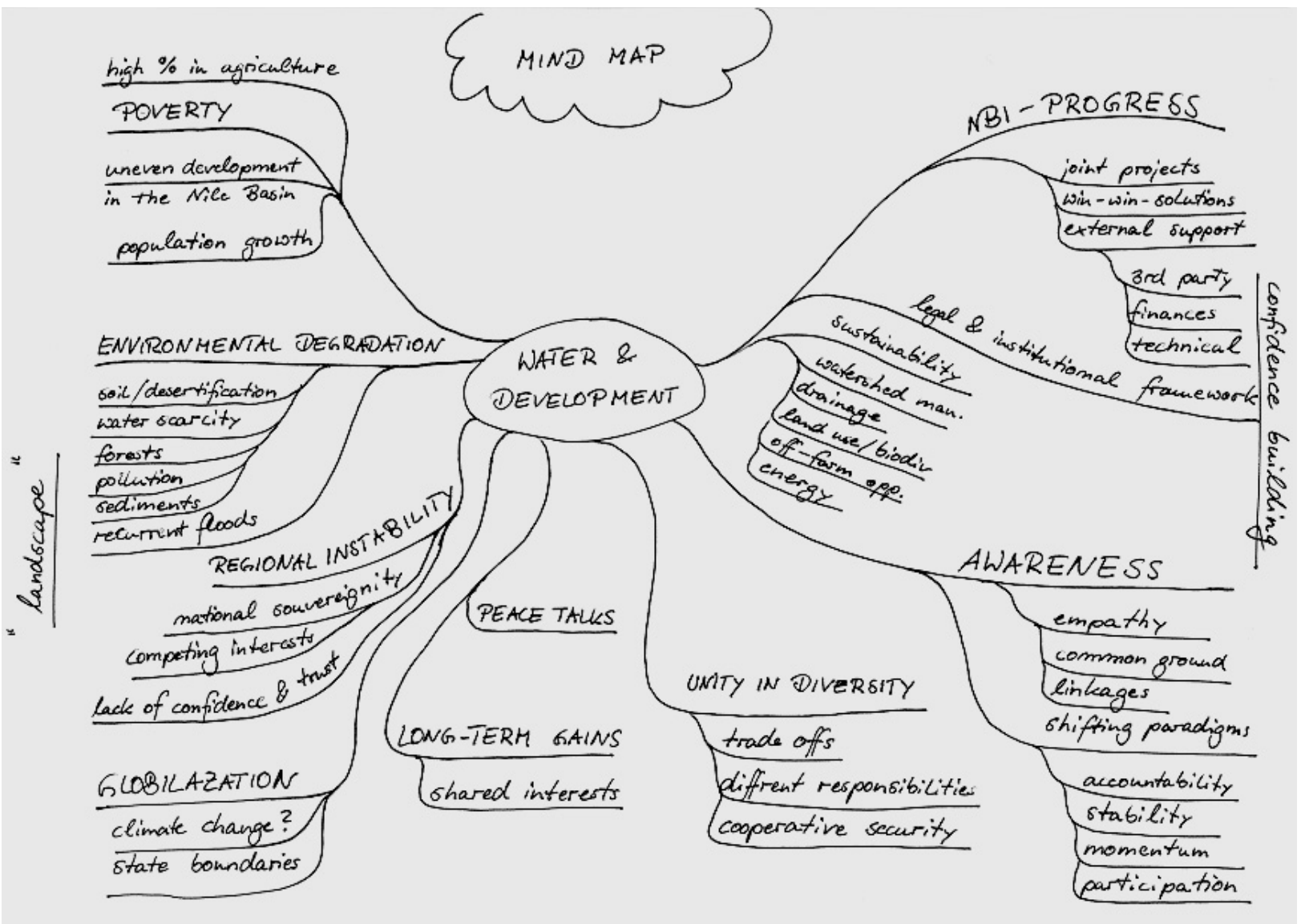

Figure 2. Mind map of challenges and opportunities in water development in the Eastern Nile Basin.

The challenge "need for institutional and legal framework" did not get a high ranking. This was not because the authors discounted its importance, but because they felt that the issue was being dealt with at the inter-governmental level, which is in fact the more competent level.

A 'mind map' was made in order to structure the issues of interest and as a means of grouping issues together. This mind map is shown in Figure 2 and summarizes some of the challenges and opportunities involved in water development in the Eastern Nile Basin.

On the left side of the mind map, the challenges are listed; on the right side, the opportunities are summarized. The four main challenges can be grouped into poverty, environmental degradation, regional instability and the challenges of globalization. The main opportunities for water development in the Nile Basin were seen in the progress of NBI, increased awareness, unity in diversity and in long-term gains.

First the challenges: some socio-economic indicators of the countries of the Nile Basin are given in Table 2. The GDP per capita, for example, ranges from US\$ 500 in Tanzania to US\$ 3,640 in Egypt in the year 1999. Eight of the 10 countries of the Nile Basin (Egypt and Kenya are the exceptions) are categorized among the 47 "least developed countries" (ECOSOC, 2001). The average population growth in the Nile Basin is $2.6 \%$. On average, $75.7 \%$ of the population lives in rural areas (UNFPA, 2001). The indicators of environmental resource availability and use are listed in Table 1 (see also Mason, 2004). The challenges of regional instability in the Nile Basin are demonstrated by the troubles in Sudan, D. R. Congo and Burundi and by the recent war between Ethiopia and Eritrea. Many water experts see regional instability as one of the main obstacles to cooperation and development. From a systems point of view, however, lack of development is also a cause of regional instability. Finally, questions of climate change are also an issue in these regions. While there is no consensus on the specific implications, general climate models predict more frequent flooding and droughts.

On the side of opportunities, the progress made by the Nile Basin Initiative was seen as a major step forward for the countries of the Nile Basin, not least of all because of the combination of a holistic approach (e.g., shared vision, legal and institutional frameworks that foster sub- 
basin projects). In line with the developments in the NBI, an increased awareness of the importance of water was identified. Shared water resources were also seen as a chance for enhancing cooperation in other fields, such as in the economic realm. In this way, water may serve as a catalyst for development. Under the category "Unity in Diversity", the opportunity to shift from a purely national concept of security to an understanding of "collective security", security through cooperation, was explored. This does not mean that a country does not first watch over its own national security; nor do countries necessarily have similar interests and responsibilities in cooperative endeavors such as the NBI. It does mean, however, that the Nile Basin countries can only guarantee their national interests in the long term through international cooperation. Furthermore, collective security implies that if all the national interests and responsibilities are pooled, trade-offs are made possible that allow for greater benefits for each of the member countries. Confidence was seen as a transversal issue and is therefore depicted vertically in the mind map.

\section{Lessons learned: from potential conflict to cooperation}

This summary of some of the "lessons learned" from the workshop include explaining the shift that took place from potential conflict towards cooperation in the Eastern Nile Basin. It also discusses ideas about what must still be accomplished to maintain the momentum gathered in cooperation and in order to deal with the open questions mentioned previously. There is broad agreement that time is needed for cooperation and trust to develop, both longterm requirements to ensure sustainable development in the Nile Basin. Many of the following points manifest a shift from an "either-or" scenario to one that is more a "this as well as that" mode of thinking.

\section{A project-by-project approach paralleled with work on legal questions}

Two key decisions broke a deadlock in the Nile Basin: (1) Ethiopia agreed to a project-by-project approach while continuing work on a legal and institutional framework, and (2) Egypt agreed to jointly develop a new legal framework, even if it is satisfied by existing agreements. The project-by-project approach means that the "shift in thinking" can happen gradually. As soon as people recognize the benefits of 'win-win' projects, they are able to acknowledge the benefits of cooperation. No one has to be committed to any legal framework that may have unforeseen implications in the long term. The advantage of having forums to talk about difficult issues, on the other hand, is that such issues have to be dealt with in order to stabilize long-term cooperation - a cooperation that exceeds and outlives any 'project-by-project' form of cooperation. A clear legal framework would also enhance the possibility of attracting international investment. Furthermore, in the long run, projects cannot remain completely detached from the larger institutional framework in which they are embedded.

\section{Acceptance of each other's needs to develop}

More concretely, cooperation has become possible in the Nile Basin Initiative because both upstream and downstream countries are increasingly accepting each other's need for water resources development.

\section{Reflective conversation, continued interaction and dialogue enhance cooperation}

A key factor in the success of the steps leading to cooperation in the Nile Basin has been the continuity of people involved in the issues, irrespective of changing governments. The growth of trust and confidence is only possible when people have the time to get to know one another over the span of years. On a larger scale, this was made possible in the informal settings provided by the series of 10 Nile 2002 Conferences, where approximately 400-500 experts, academics, journalists and other interested people met and exchanged perspectives on Nile water issues. Since they were held in different Nile countries, it also allowed many people to see the Nile question from different perspectives. All of these official and nonofficial forums have led to a "dialogue accumulation". Individual meetings, forums or conferences alone do not create trust. Together and over time, however, trust may develop, and this is the cornerstone of cooperation, which in its turn is the cornerstone of sustainable development of shared resources. In general, a "reflective conversation", trying to jointly look at the problem, is more fruitful than a debate on who is right or wrong. The idea of this reflective conversation is to enter into each other's territory of thought, and thus to better understand the others' views.

\section{Cooperation is an interactive learning process}

Interaction between the Nile countries in various fields is one way of mitigating distrust and increasing mutual respect and awareness of interdependency. Such forms of interaction that could be further developed include greater trade links, exchange of students and academics, awareness and exchange of cultural richness, common religious heritages, and joint scientific projects. 


\section{Solving the problem on the right level}

The open questions concerning legal and institutional issues are being discussed in the D3 project by the Panel of Experts, where some of the differences have been clarified. The ones over which there is still disagreement are now being dealt with in the Negotiating Committee. In other words, one way of dealing with open questions is to try to solve them on increasing levels of political influence, starting at the level of technicians, and then, as the issues remain unresolved or delicate, transferring them to a higher political level, to the Nile-COM, and then finally to the highest political level.

\section{Coordinated third-party assistance}

There is a broad consensus that facilitation, financial and communication assistance from a third party that works in a transparent and coordinated way greatly enhances the chances of cooperation. In the case of the Nile Basin it was the World Bank, UNDP, CIDA and others whose efforts were channeled through the Nile Basin Initiative, this in contrast to the many examples of ill-coordinated third-party assistance in other international river basins.

\section{End of cold war, change in time period}

The end of the cold war meant that Egypt and Ethiopia, previously in different camps, both began to interact in a more cooperative spirit. This enabled cooperation over issues such as water resources, which was previously not possible due to the priorities set by ideology and allegiances. Countries that cooperate have to see the benefit of cooperation over the benefit of threats or of ignoring the problems.

\section{Factual basis of the effects of the project helps to ease fears}

Research is needed on the effects of water development projects. Research and pilot projects can help to better know the implications of different projects and thus create a factual basis for their assessment.

\section{Greater public participation}

Over the years, the issue of international Nile water use has increasingly become a public theme that is discussed in the media. This allows for greater feedback from the public, and it also enhances the public's acceptance of its respective government's strategy of cooperation, especially when the benefits are clarified. If a water development project affects a certain group of the population directly, this group must also benefit directly from the project, and its acceptance of the project should be gained before the project commences.
While some of these lessons learned are specific to the Nile Basin, many are of value to other international rivers, as well as other internationally shared resources. The Nile Basin shows that different interests, needs and responsibilities concerning a shared resource have to be viewed together, allowing for trade-offs among the involved nations. A country only cooperates when it perceives a benefit from cooperation. Win-win projects, however, do not mean that each country benefits equally from each project, but that each country benefits directly or indirectly from the total number of projects in which the countries agree to participate. The Nile Basin demonstrates that different cooperative efforts can be followed at the same time, even if it is essential that this happens in a coordinated manner. The planning and implementation of projects on the ground, as well as the development of an institutional framework, can therefore be part and parcel of the same cooperative initiative. Both approaches are needed; the question is how to coordinate them. The role of a third party may thus be to support the coordination, as well as to assist with facilitation, financing and communication. In the Nile Basin, the third parties (World Bank, UNDP and CIDA) seem to have been successful in doing this while at the same time leaving the ownership of the process in the hands of the Nile Basin states - an important reason for its success. Win-win packages and work on institutional change ${ }^{7}$ and communication that leads to trust and confidence are ingredients that lead to cooperation; and cooperation over shared resources is a prerequisite for achieving the ultimate aim of sustainable development.

The EAWAG-CIS workshop aimed to create an environment that facilitated exchange based on the expertise of independent scholars. Further issues not dealt with during the first Dialogue Workshop on the Nile were treated in more depth in subsequent Nile Dialogue Workshops in 2003 and 2004, supported by the Swiss Agency for Development and Cooperation (SDC) and NCCR North-South. This introduction should not be considered as the proceedings of the first Nile Dialogue workshop of 2002 ; its aim is rather to provide an overview of the issues dealt with in the following papers.

\section{Conclusion}

The conclusion to this introduction paper is grouped into three points: 1) the past challenges, 2) the achievements of the present process beginning with the dialogue on the Cooperative Framework since 1997 and the Nile Basin Initiative since 1999, and 3) the next steps to be taken.

\footnotetext{
7 Institutional change is understood here as patterns and norms of behavior that shape and stabilize human actions, moving in the direction of greater satisfaction of all identified needs.
} 
The lack of a joint basin institution and an agreed legal framework for cooperation between the countries of the Nile must be understood in the light of historical developments. Population growth in all the countries means that water increasingly needs to be developed for food and energy production. This increased pressure to use the water resources of the Nile can lead to tension - e.g. as it did in the past - or to cooperation, as is happening now.

The common determination to cooperate is perhaps best signaled by the launching of the Nile Basin Initiative (NBI) in 1999. For the first time in the history of the Nile all countries (except Eritrea so far) became active members of a basin wide partnership aiming at the joint use of the Nile waters for the benefit of all. This shift was made possible because the countries of the Nile Basin accepted to discuss legal issues and to go forward on a project-byproject basis at the same time. While this initiative is still a transitional mechanism, there are optimistic signs especially in the year 2004 of negotiations that will lead to a Nile Basin Commission. The NBI and the Nile 2002 Conference Series as well as smaller exercises such as the Nile Dialogue Workshop Series, created vessels of communication that have led to growing trust between the countries. A key concept here is "Dialogue Accumulation", i.e. that not one workshop or conference leads to a new spirit of cooperation, but many exchanges are needed. This form of communication seeks understanding rather than polemical debate. This approach of cooperation through communication was aptly expressed in the words of the participants of the 2004 Nile Dialogue Workshop as follows: "When we empathetically engage with (rather than resist or push against) a person or situation we experience as an obstacle, we can release and re-

Table 4. Meaning of slogans used in this article.

Sustainable development: Socio-economic development that safeguards the resource base for future generations, taking possible long-term and off-site resource use implications into consideration

Institutional change: Patterns and norms of behavior that shape and stabilize human actions, moving in the direction of greater satisfaction of all identified needs (see also Bandaragode, 2000).

Participatory approach: The participatory approach is understood here to mean specifically the involvement of all riparian countries in decision-making, as they are directly affected by any water development projects in the Nile Basin. Outsiders play a facilitating and supporting role (see also Delli Priscoli, 1993).

Integrated water resource management: An intersecting approach that considers physical aspects of water resources, environmental sustainability, and all relevant stakeholders

Systems view: A holistic approach that is based on a comprehensiveness and interconnectedness of hydrological, economic, political, social and environmental concerns, with humans at the center of the complex management problem. Problems are tackled simultaneously because they are linked (see also Le Moigne, 1996). direct the energy held in that situation toward a positive end."

What are the next steps to be taken? In a nutshell, the challenge is to move from vision and common understanding, something that has been created during the last five years, to action on the ground. This action on the ground needs to be guided by agreed upon rights and duties of all participants, in a flexible yet binding institutional set-up. A Nile Basin Commission needs to be created - and negotiations in 2004 are getting closer to this

Table 5. Acronyms.

\begin{tabular}{|c|c|}
\hline CIDA & Canadian International Development Agency \\
\hline $\mathrm{CNS}$ & Comprehensive National Strategy (Sudan) \\
\hline D3 & $\begin{array}{l}\text { Forum for developing the "Nile Basin Cooperative } \\
\text { Framework" for the management of the Nile }\end{array}$ \\
\hline EEC & European Economic Community \\
\hline EN & Eastern Nile \\
\hline ENCOM & Eastern Nile Council of Ministers \\
\hline ENSAP & Eastern Nile Subsidiary Action Program \\
\hline ENTRO & Eastern Nile Technical Regional Office \\
\hline ESA & External Support Agency \\
\hline ETB & $\begin{array}{l}\text { Ethiopian Birr; } 8 \text { Birr is approximately equivalent } \\
\text { to } 1 \text { US\$, } 2002\end{array}$ \\
\hline EVDSA & Ethiopian Valleys Development Studies Authority \\
\hline FAO & $\begin{array}{l}\text { Food and Agriculture Organization of the United } \\
\text { Nations }\end{array}$ \\
\hline FDA & Foreign Direct Investment \\
\hline HEP & Hydro-electric power \\
\hline HIPC & Heavily Indebted Poor Countries \\
\hline Hydromet & $\begin{array}{l}\text { Hydrometeorological Survey of the Catchments of } \\
\text { Lakes Victoria, Kyoga and Mobuto Seseko }\end{array}$ \\
\hline IBRD & $\begin{array}{l}\text { International Bank for Reconstruction and Devel- } \\
\text { opment (World Bank) }\end{array}$ \\
\hline ICCON & $\begin{array}{l}\text { International Consortium for Cooperation on the } \\
\text { Nile }\end{array}$ \\
\hline IDA & International Development Association \\
\hline ILC & International Law Commission \\
\hline IMF & International Monetary Fond \\
\hline NBI & Nile Basin Initiative \\
\hline NEL & Nile Equatorial Lakes \\
\hline NELSAP & Nile Equatorial Lakes Subsidiary Action Program \\
\hline Nile COM & $\begin{array}{l}\text { Council of Ministers of Water Affairs of the Nile } \\
\text { Basin States }\end{array}$ \\
\hline Nile SEC & Nile Basin Initiative Secretariat \\
\hline Nile TAC & $\begin{array}{l}\text { Nile Basin Initiative Technical Advisory Commit- } \\
\text { tee }\end{array}$ \\
\hline NRBAP & Nile River Basin Action Plan \\
\hline ODA & Official Development Assistance \\
\hline PJTC & Permanent Joint Technical Committee \\
\hline POE & Panel of Experts \\
\hline PRSP & Poverty Reduction Strategy Paper \\
\hline SAP & Subsidiary Action Program \\
\hline SVP & Shared Vision Program \\
\hline TECCONILE & $\begin{array}{l}\text { Technical Cooperation Committee for Promotion } \\
\text { of the Development and Environmental Protection } \\
\text { of the Nile Basin }\end{array}$ \\
\hline UNDP & United Nations Development Program \\
\hline UNECA & United Nations Economic Commission for Africa \\
\hline UNEP & United Nations Environment Program \\
\hline WMO & $\begin{array}{l}\text { World Meteorological Organization, } \\
\text { A United Nations Specialized Agency }\end{array}$ \\
\hline WRI & World Resources Institute \\
\hline WTO & World Trade Organization \\
\hline
\end{tabular}


goal - based on the common denominator between all the involved countries. Patience is necessary to analyze concrete projects in depth before construction begins, as is happening in the feasibility studies and in the first group of agreed-upon investment projects that are presently underway and should be finished in the next 2-3 years. The assessment of projects also includes participatory processes, where NGOs and civil society are consulted. Only by bringing civil society on board at an early stage will the projects be sustainable. The acquisition of finances is a further key challenge to be dealt with. While financial investment from outside the region is urgently needed, ownership of the process and projects must remain in the hands of the Nile countries.

\section{Acknowledgments}

The authors acknowledge support from the Individual Project 7 "Environmental Change and Conflict Transformation" (CSS-ETH/Swisspeace/Ethno-Unizh) of the Swiss National Centre of Competence in Research (NCCR) North-South: Research Partnerships for Mitigating Syndromes of Global Change. The NCCR NorthSouth is co-funded by the Swiss National Science Foundation (SNF) and the Swiss Agency for Development and Cooperation (SDC). Furthermore, support from the Swiss Federal Institute of Environmental Science and Technology (EAWAG) and the Center for Security Studies (CSS-ETH), a member of the Center for Comparative and International Studies of the Swiss Federal Institute of Technology (CIS-ETH Zurich) are also gratefully acknowledged.

\section{References}

Agreement, 1959. Agreement between the Republic of the Sudan and the United Arab Republic for the full utilization of the Nile Waters signed at Cairo Egypt, 8 November 1959. In: FAO Legislative Study - 61, Food and Agriculture Organization, available online at: <http://www.fao.org/docrep/W7414B/ w7414b13.htm $>(10.11 .2004)$.

Arsano, Y. and I. Tamrat, 2005. Ethiopia and the Eastern Nile Basin. Aquat. Sci. 67(1): 15-27.

Arsano, Y., forthcoming. Ethiopia and the Nile, Dilemmas of National and Regional Hydropolitics, Center for Security Studies, Swiss Federal Institute of Technology, ETH Zürich.

Bandaragode, D. J., 2000. A framework for institutional analysis for water resources management, International Water Management Institute, Working Paper 5, Colombo, Sri Lanka.

Collins, R. O., 1990. The Waters of the Nile, Hydropolitics and the Jonglei Canal 1900-1988, Claredon Press, Oxford.

Conway, D., 2000. The climate and hydrology of the upper Blue Nile Basin. The Geographical Journal 166: 49-62.

Delli Priscoli, J., 1993. The Development of Transnational Regimes for Water Resources Management, Vol. II. Aswan, Egypt.
ECOSOC, 2001. Economic and Social Council, United Nations Conference on Trade and Development UNCTAD <http:// www.unctad.org/en/pub/ldcprofiles2001.enhtm> 10.10.2002).

Egypt, 2000. Country paper of the Arab Republic of Egypt. In: Proceedings, Comprehensive Water Resources Development of the Nile Basin: Priorities for the New Century, VIII Nile 2002 Conference, June 26-30, Addis Ababa, pp 38-53.

Ethiopia, 2000. Country paper of the Federal Democratic Republic of Ethiopia. In: Proceedings, Comprehensive Water Resources Development of the Nile Basin: Priorities for the New Century, VIII Nile 2002 Conference, June 26-30, Addis Ababa, pp $54-56$.

EVDSA (Ethiopian Valleys Development Studies Authority), 1991. Ethio-Sudanese Relations with Respect to Water Resources, Amharic monograph, Addis Ababa.

Falkenmark, M. and C. Widstrand, 1992. Population and water resources: a delicate balance. Population Bulletin 47: 1-36.

FAO (Food and Agriculture Organization of the United Nations), 1997a. Irrigation Potential in Africa, A Basin Approach, Rome $<$ http://www.fao.org/docrep/w4347e/w4347e00.htm> (09.11.2004).

FAO (Food and Agriculture Organization of the United Nations), 1997b. Irrigation in the Near-East Region in Figures, Rome $<$ http://www.fao.org/docrep/w4356e/w4356e00.htm\#Contents $>(09.11 .2004)$

FAO (Food and Agriculture Organization of the United Nations), 2000. FAOSTAT Agriculture Data, Rome <http://apps.fao.org/ page/collections? subset=agriculture $>$ (04.12.2000).

Gleick, P. H., 1998. The World's Water 1998-1999: The Biennial Report on Freshwater Resources, Washington, D.C., tables available online at: <http://www.worldwater.org/table2.html> (01.12.2000).

Hamad, O. E.-T. and A. El-Battahani, 2005. Sudan and the Nile Basin. Aquat. Sci. 67(1): 28-41.

Hefny, M. and S. E.-D. Amer, 2005. Egypt and the Nile Basin. Aquat. Sci. 67(1): 42-50

Le Moigne, K., 1996. Fostering Riparian Cooperation in International River Basins: The World Bank at its Best in Development Diplomacy, The World Bank, Washington.

Mason, S.A., 2004. From Conflict to Cooperation in the Nile Basin. Center for Security Studies, Swiss Federal Institute of Technology, ETH Zurich, available online at: <http://www.css.ethz.ch/ publications/mason $>(05.10 .2004)$.

Mekonnen A. and T. Deksios, 2001. Water Resources of Ethiopia. In: Water Development, Quarterly, Magazine of the Ministry of Water Resources (in Amharic, English translation by Yacob Arsnao), Addis Ababa.

NBI (Nile Basin Initiative), 2000. Nile River Basin, History of the Nile Basin Initiative $<$ http://www.nilebasin.org $>$ (06.10.2002).

NBI (Nile Basin Initiative), 2001. Nile River Basin. Transboundary Environmental Analysis, World Bank, Washington.

Seckler, D., U. Amarasinghe, D. Molden, R. de Silva and R. Barker, 1998. World water demand and supply, 1990 to 2025: scenarios and issues, research report 19, International Water Management Institute (IWMI), Colombo, Sri Lanka <http://www. cgiar.org/iwmi/pubs/PUB019/RR019.thm> (05.03.2002).

UNFPA (United Nations Population Fund), 2000. The State of the World Population 2000, Demographic, Social and Economic Indicators, New York <http://web.unfpa.org/swp/2000/english/indicators/indicators2.html $>(10.12 .2000)$.

UNFPA (United Nations Population Fund), 2001. The State of World Population 2001, Demographic, Social and Economic Indicators, New York <http://web.unfpa.org/swp/2001/english/indicators/indicators $2 . h t m l>(11.10 .2002)$

WRI, World Resources Institute, 1998. World Resources 1998-99, Freshwater Resources and Withdrawals 1970-98, Data Table 12.1, <http://www.wri.org/wri/wr-98-99/pdf/wr98_wa1.pdf $>$ (05.12.2000). 